\title{
Role of cytology, colposcopy and biopsy in the detection of cervical intraepithelial neoplasia
}

\author{
Pooja H. Khakhla*, R. Anand, Jyoti G. Sharma, Bhargav B. Boghara
}

Department of Obstetrics and Gynaecology, S.B.K.S. Medical Institute and Research Centre, Dhiraj General Hospital, Sumandeep Vidyapeeth, Pipariya, Vadodara, Gujarat, India

Received: 19 September 2013

Accepted: 28 October 2013

*Correspondence:

Dr. Pooja H. Khakhla,

E-mail: pooja.khakhla@gmail.com

(C) 2013 Khakhla PH et al. This is an open-access article distributed under the terms of the Creative Commons Attribution Non-Commercial License, which permits unrestricted non-commercial use, distribution, and reproduction in any medium, provided the original work is properly cited.

\begin{abstract}
Background: Cervical cancer is both preventable and curable. It has a long natural history with a prolonged precancerous phase that is easily detectable and treatable. Exfoliative cervical cytology remains the mainstay for screening of pre-cancerous lesions (cervical intraepithelial neoplasia, CIN). In this study we discuss role of cytology, colposcopy and biopsy in the detection of cervical intraepithelial neoplasia.

Methods: This is a prospective observational study done at the Department of Obstetrics and Gynecology, Dhiraj General Hospital from April 2013 for a period of 4 months. Total of 200 eligible women were enrolled for the study.

Results: Colposcopy was well-correlated with histology in $69.70 \%$ cases. Cytology was well-correlated with histology in $65.15 \%$ of cases \& with major discrepancy in $18.18 \%$ cases.

Conclusion: The incidence of cervical cancer will continue to be very high in our population because of the constant high incidence of early marriage, multiparity, poor nutrition, poor hygiene, and low living standards. Thus there is a need for screening of these patients for cervical cancer and till date exfoliative Cytology has been found to be the Gold Standard for detection of early malignancy. Universal cytologic screening of all sexually active women should be done, especially in cases of parous women in lower socio-economic groups. Treatment \& follow-up of dysplasia could prevent malignancies in future.
\end{abstract}

Keywords: Cytology, Colposcopy, Biopsy, Cervical Intraepithelial Neoplasia

\section{INTRODUCTION}

Cervical cancer is both preventable and curable. It has a long natural history with a prolonged pre-cancerous phase that is easily detectable and treatable. Exfoliative cervical cytology remains the mainstay for screening of precancerous lesions (cervical intraepithelial neoplasia, CIN). ${ }^{6,2}$ Assessment of women presenting with abnormal cervical cytology and the selection of those requiring treatment relies mainly on colposcopic impressions of the cervical transformation zone and histological appraisal of directed punch biopsies. There is variation in the assessment of cytology, colposcopy and histology findings, and therefore the 'final' diagnosis involve of all three disciplines. ${ }^{5,8}$ The need to maximize clinical resources, achieve quicker and more effective management of patients, limit postoperative complications and preserve reproductive function has led to the popularity of local excisional methods for cervical premalignancy. ${ }^{7}$ Although the cure rates for all local ablative and excisional methods are more than $90 \%$ after one treatment, the excisional methods provide a more reliable histopathological diagnosis and the patient may be treated at the initial visit. Cure rates for CIN correlate principally with the extent of the CIN. More than $95 \%$ of cervical cancer cases are associated with oncogenic types of human papillomavirus. ${ }^{1,3}$

\section{Aims \& Objectives}

1. To screen the sexually active female population for early detection of neoplastic lesions of cervix 
by using pap smear, colposcopy and biopsy if required.

2. To study the factors of etiological significance in the patients with precancerous lesions and to evaluate them in the light if present knowledge.

3. To correlate cytological as well as histological diagnosis.

4. To attempt to correlate the clinical presentation with colposcopic finding and histological report.

5. Management of patients diagnosed to have early cervical cancer.

6. To create awareness about combined use of Pap smear, colposcopy and SOS biopsy for diagnosis of precancerous lesion of cervix.

\section{METHODS}

This is a prospective study of 200 cases. Patients were selected at Gynecology OPD, Dhiraj general hospital, Piparia, Vadodara from April 2013 for a period of 4 months.

\section{Inclusion Criteria}

Patients with complaint of

1. Persistent whitish discharge, with suspicious cervix

2. Menstrual irregularities

3. Contact bleeding

4. Post coital bleeding

\section{Exclusion Criteria}

1) Known case of Carcinoma Cervix

2) Nulliparous unmarried

3) Sexually inactive

4) Hysterectomised

5) Previous conization or treatment for CIN

These cases were randomly selected for study. Detailed history was taken and thorough general examination of all patients was done. Now the complete gynecological examination including $\mathrm{P} / \mathrm{S}, \mathrm{P} / \mathrm{V}$ and $\mathrm{SOS} \mathrm{P} / \mathrm{R}$ examination was done and after selecting the patient for colposcopy, patients were called after a week for study.

During follow up visit, first of all $\mathrm{P} / \mathrm{S}$ was done with good light of colposcope and an adequate size unlubricated Cusco's speculum. Cervix was examined carefully and Pap smear was taken. Then colposcopy of all patients was done with Carl Zeiss colposcope under guidance of professors and assistant professors.

After taking Pap smear, cervix was cleaned with normal saline, then $3 \%$ acetic acid was applied to remove mucus and thorough examination was done under magnification and green filter.
Colposcopic findings were mapped in the case paper. From colposcopic examination, histology was predicted and recorded as CIN I, II \& III and in all suspicious cases colposcopic guided biopsy (either punch or excision) was taken. If upper limit of lesion was not seen, endocervical curettage was done. After completely investigating the patient with pap smear, colposcopy and biopsy, management was planned accordingly.

\section{RESULTS}

Table 1: Age distribution.

\begin{tabular}{|lll|}
\hline $\begin{array}{l}\text { Age } \\
\text { groups(years) }\end{array}$ & $\begin{array}{l}\text { No. Of } \\
\text { patients }\end{array}$ & Percentage $(\%)$ \\
\hline$</=20$ & 2 & 1.0 \\
\hline $21-30$ & 50 & 25.0 \\
\hline $31-40$ & 89 & 44.5 \\
\hline $41-50$ & 41 & 20.5 \\
\hline $51-60$ & 13 & 6.5 \\
\hline$>60$ & 5 & 2.5 \\
\hline Total & $\mathbf{2 0 0}$ & $\mathbf{1 0 0}$ \\
\hline
\end{tabular}

It is seen that maximum numbers of patients were in the age group of $3^{\text {rd }}-4^{\text {th }}$ decades.

Table 2: Locality wise distribution.

\begin{tabular}{|lll|}
\hline Locality & $\begin{array}{l}\text { No. Of } \\
\text { patients }\end{array}$ & Percentage $(\%)$ \\
\hline Urban & 135 & 67.5 \\
\hline Rural & 65 & 32.5 \\
\hline Total & $\mathbf{2 0 0}$ & $\mathbf{1 0 0}$ \\
\hline
\end{tabular}

Regarding locality of the patients it was observed that $67.5 \%$ of cases were from the urban areas while $32.5 \%$ were from rural areas. Because CIN has no symptoms, patients from rural areas do not report earlier and it also shows awareness in the people from the urban area regarding their health checkup and awareness regarding their health.

In our study one-fifth of patients had normal cervix, while others had some abnormalities in the form of Erosion, Suspicious (hyperthyroid), polyp or growth.

Patients with normal looking cervix showed mild dysplasia and only in one case dysplasia was found but invasive carcinomas were not seen. It is a known fact that cytology or histological evidence of dysplasia can be only sign of these lesions in a seemingly normal cervix and an asymptomatic patient. ${ }^{4}$ 
Table 3: Cervical lesions and its correlation with dysplasia.

\begin{tabular}{|c|c|c|c|c|c|c|c|c|c|c|c|c|}
\hline \multirow{2}{*}{$\begin{array}{l}\text { Appearance } \\
\text { of cervix }\end{array}$} & \multicolumn{2}{|c|}{ Total pts } & \multicolumn{2}{|c|}{ CIN-I } & \multicolumn{2}{|c|}{ CIN-II } & \multicolumn{2}{|c|}{$\begin{array}{l}\text { CIN-III/ } \\
\text { CIN-III + } \\
\text { CIS }\end{array}$} & \multicolumn{2}{|c|}{ Invasive } & \multicolumn{2}{|c|}{$\begin{array}{l}\text { Percentage of } \\
\text { dysplasia }\end{array}$} \\
\hline & N1 & $\begin{array}{l}\% \text { of } \\
\text { N1 }\end{array}$ & No. & $\begin{array}{l}\% \text { of } \\
\text { N1 }\end{array}$ & No. & $\begin{array}{l}\% \text { of } \\
\text { N1 }\end{array}$ & No. & $\begin{array}{l}\% \text { of } \\
\text { N1 }\end{array}$ & No. & $\begin{array}{l}\% \text { of } \\
\mathrm{N} 1\end{array}$ & No. & $\begin{array}{l}\% \\
\text { of } N 1\end{array}$ \\
\hline Normal & 39 & 19.5 & 2 & 5.13 & - & - & 1 & 2.56 & - & - & 3 & 7.69 \\
\hline Erosion & 97 & 48.5 & 10 & 10.31 & 1 & 1.03 & 4 & 4.12 & 2 & 2.06 & 17 & 17.52 \\
\hline Suspicious & 61 & 30.5 & 6 & 9.84 & 4 & 6.56 & 8 & 13.11 & 6 & 9.84 & 24 & 39.34 \\
\hline Polyp & 2 & 1 & - & - & - & - & - & - & - & - & - & - \\
\hline Growth & 1 & 0.5 & - & - & - & - & - & - & 1 & 100 & 1 & 100 \\
\hline Total & 200 & & 18 & & 5 & & 13 & & 9 & & 45 & 22.5 \\
\hline
\end{tabular}

Table 4: Classification of cytological smears report.

\begin{tabular}{|lll|}
\hline Smears & $\begin{array}{l}\text { No. of } \\
\text { patients }\end{array}$ & Percentage (\%) \\
\hline Normal & 48 & 24.49 \\
\hline Inflammatory & 101 & 51.53 \\
\hline CIN-1 & 19 & 9.69 \\
\hline CIN-2 & 8 & 4.08 \\
\hline CIN-3 & 12 & 6.12 \\
\hline Invasive & 6 & 3.06 \\
\hline Unsatisfactory & 2 & 1.02 \\
\hline Total & $\mathbf{1 9 6}$ & $\mathbf{1 0 0}$ \\
\hline
\end{tabular}

Cytological smears were taken in 196 patients only. In the present study normal smears were found in $24.49 \%$ cases, inflammatory in $51.53 \%$ cases and dysplastic smear found in $19.89 \%$ cases \&malignancy in $3.06 \%$ smears.

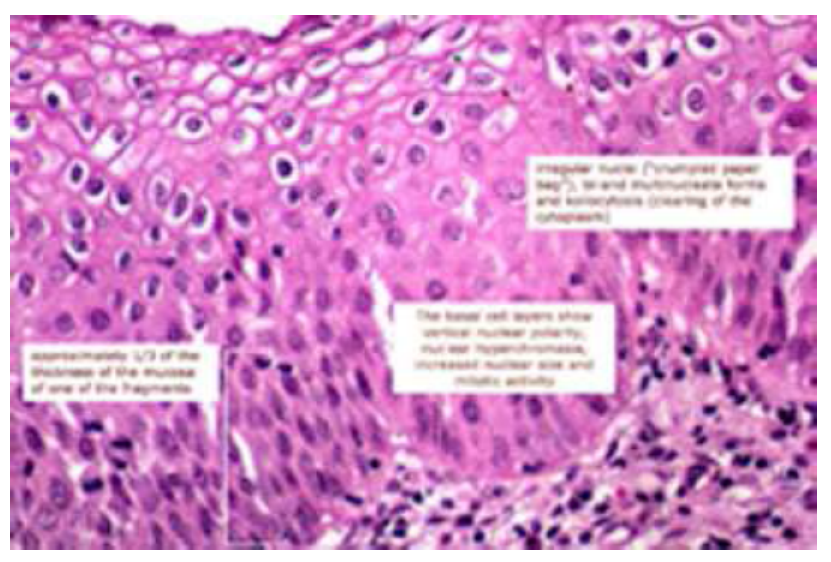

Table 5: Colposcopic findings.

\begin{tabular}{|lll|}
\hline $\begin{array}{l}\text { Colposcopic } \\
\text { finding }\end{array}$ & $\begin{array}{l}\text { No. of } \\
\text { patients }\end{array}$ & Percentage \\
\hline Normal & 110 & 55.0 \\
\hline Inflammatory & 31 & 15.5 \\
\hline CIN-1 & 26 & 13.0 \\
\hline CIN-2 & 8 & 4.0 \\
\hline CIN-3 & 14 & 7.0 \\
\hline Invasive & 2 & 1.0 \\
\hline Unsatisfactory & 9 & 4.5 \\
\hline Total & $\mathbf{2 0 0}$ & $\mathbf{1 0 0}$ \\
\hline
\end{tabular}

In present study out of 200 cases, 48 patients (24\%) showed dysplasia of various grades on colposcopy and 2 patients $(1 \%)$ showed invasive cancer.

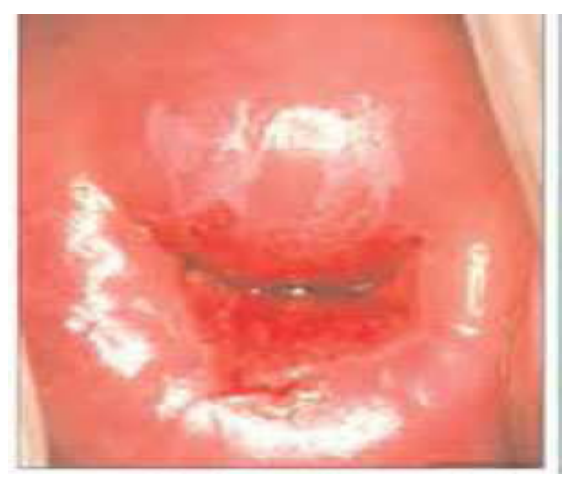

Cervigram photograph after the application of vinegar. Immature transformation zone. SCJ completely visible. Low-grade lesions visible as acetowhite epithelium attached to the squamo columnar junction on the anterior ectocervix. 
Table 6: Correlation between cytological and histological diagnosis.

\begin{tabular}{|c|c|c|c|c|c|c|c|c|}
\hline $\begin{array}{l}\text { Cytology/ } \\
\text { histology }\end{array}$ & Normal & Inflammatory & CIN-1 & CIN-2 & $\begin{array}{l}\text { CIN-3 \& } \\
\text { CIN-3 + } \\
\text { CIS }\end{array}$ & Invasive & $\begin{array}{l}\text { Un- } \\
\text { satisfactory }\end{array}$ & Total \\
\hline Normal & 3 & 3 & 1 & 1 & - & - & - & 8 \\
\hline Inflammatory & 6 & 3 & 8 & 1 & 2 & - & - & 20 \\
\hline CIN-1 & 2 & 2 & 7 & - & - & - & - & 11 \\
\hline CIN-2 & - & 2 & 1 & 3 & 2 & - & - & 8 \\
\hline CIN-3 & - & - & - & - & 9 & 3 & - & 12 \\
\hline Invasive & - & - & - & - & - & 6 & - & 6 \\
\hline Un-satisfactory & - & - & 1 & - & - & - & - & 1 \\
\hline Total & 11 & 10 & 18 & 5 & 13 & 9 & - & 66 \\
\hline
\end{tabular}

Table 7: Management of patients.

\begin{tabular}{|c|c|c|c|c|c|}
\hline Procedure & CIN-1 & CIN-2 & $\begin{array}{l}\text { CIN-3 \& CIN- } \\
3+\text { CIS }\end{array}$ & Invasive & $\begin{array}{l}\text { For other gynaecological } \\
\text { cause }\end{array}$ \\
\hline $\begin{array}{l}\text { Total abdominal } \\
\text { hysterectomy }\end{array}$ & - & 2 & 4 & - & $\begin{array}{l}5 \\
-4 \text { DUB } \\
-1 \text { adenomyosis }\end{array}$ \\
\hline Panhysterectomy & - & - & 5 & - & - \\
\hline Vaginal hysterectomy & 4 & 2 & 5 & - & $\begin{array}{l}8 \\
-5 \text { prolapse } \\
-2 \text { pain in abdomen } \\
-1 \text { DUB }\end{array}$ \\
\hline $\begin{array}{l}\text { Wertheim's } \\
\text { hysterectomy }\end{array}$ & - & - & - & 2 & - \\
\hline Radiotherapy & - & - & - & 2 & - \\
\hline
\end{tabular}

In the present study good agreement between cytological $\&$ histological diagnosis was found in $65.15 \%$ and major Discrepancy found in $18.18 \%$ cases i.e. $18.18 \%$ cases had a disagreement of at least two grade of CIN. In 5 patients (7.5\%) smear predicted a higher grade of CIN than that observed on biopsy while in 10 patients $(15.15 \%)$ the smear had underestimated the severity of CIN seen histologically.

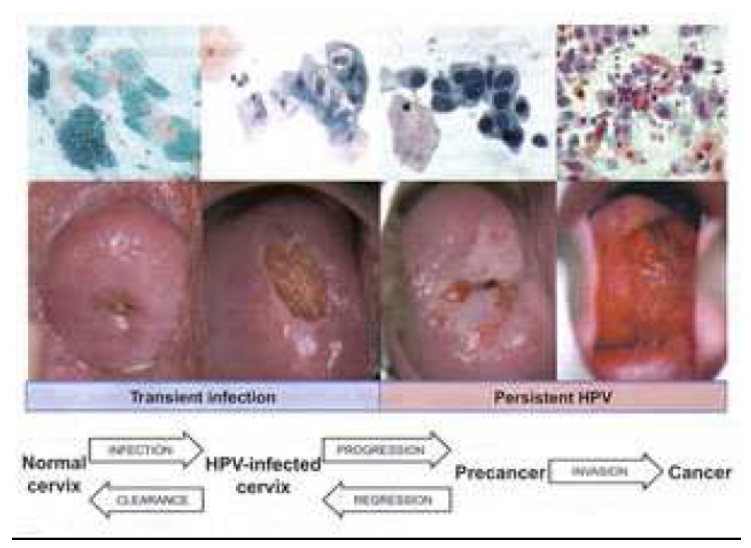

Total 35 patients were underwent hysterectomy,

- 11 cases had total abdominal hysterectomy,

- 4 for CIN-3 with CIS

- 2 for CIN-2

- $\quad 5$ for other gynaecological cases

- 5 cases had panhysterectomy

- 5 for CIS with microinvasion

- 19 cases had vaginal hysterectomy

- 5 for CIN-3 with CIS

- 2 for CIN-2

- 4 for CIN-1

- 8 for some other gynaecological causes

- 2 cases had Wertheim's hysterectomy

- $\quad 2$ for invasive cancer early stage ( $2 a$ \& $1 b$ )

- 2 cases had radiotherapy

- $\quad 2$ for late stage cancer (3b) 


\section{DISCUSSION}

The discrepancy between cytology \& histology could be due to error of interpretation of changes in cells identified by screener \& failure to identify malignant cells. Collection of cervical smears may result in sampling error, faulty technique \& is well documented that malignant cells occasionally simply fail to exfoliate.

So, significant improvement in the correlation between cytology \& histology can be achieved by a careful review of initially discrepant results.

\section{CONCLUSION}

In India, the emphasis on diagnosis is, at last, beginning to shift from late cases to early cases of cervical cancer. This has been possible due to the introduction of cytology in many of the centers in the last decade. The introduction of colposcopy has further improved the quality of management of these cases. Colposcopy being a specialized technique needs training \& constant practice. Therefore there is a urgent need to develop further expertise in colposcopy, especially in a developing countries like India.

The incidence of cervical cancer will continue to be very high in our population because of the constant high incidence of early marriage, multiparity, poor nutrition, poor hygiene, and low living standards. Thus there is a need for screening of these patients for cervical cancer and till date exfoliative Cytology has been found to be the Gold Standard for detection of early malignancy. Universal cytologic screening of all sexually active women should be done, especially in cases of parous women in lower socio-economic groups. Treatment \& follow-up of dysplasia could prevent malignancies in future.

Prevention is always better than cure, therefore we should stress more on education, prevention and treatment of STDs, family planning measures, widespread use of cytologic screening, good referral system of patients with CIN to the more thoroughly centers and of course, utilization of all possible resources for proper management $\&$ follow up of these cases. It will decrease the morbidity as well as mortality associated with invasive cancer of cervix.

\section{Funding: None \\ Conflict of interest: None declared \\ Ethical approval: The study was approved by the Institutional Ethics Committee}

\section{REFERENCES}

1. Seung Jo Kim. Role of Colposcopy and cervicography in screening and management of precancerous lesions and early invasive cancer of uterine cervix. J Obstet Gynecol India. 2000 Oct;50(5):139-146.

2. Richard RM. Natural history of cervical intraepithelial neoplasia. Clin Obstet Gynecol 1968;10:748-84.

3. Fahey MT, Irwig L, Macaskill P. Meta-analysis of Pap test accuracy. Am J Epidemiol. 1995 Apr $1 ; 141(7): 680-9$.

4. Arora R. Cervical Cancer: a clinical approach. Obs and Gyane Today, 1999 Nov;4(11):658-666.

5. Donohue LR, Meriwether W. Colposcopy as a diagnostic tool in the investigation of cervical neoplasias. Am J Obstet Gynecol. 1972 May 1;113(1):107-10.

6. Miller A: Screening for cervical cancer, in Rubin SC, Hoskins, WJ (eds): Cervical Cancer and Preinvasive Neoplasia. Philadelphia, Pa., Lippincott-Raven, 1996, pp 13-25.

7. Saraiya UB. Screening for cervical cancer. FOGSI Focus 1993 May;3.

8. Crisp WE, Craine BL, Craine EA. The computerized digital imaging colposcope: future directions. Am J Obstet Gynecol. 1990 Jun;162(6):1491-7; discussion 1497-8.

DOI: $10.5455 / 2320-1770$. ijrcog20131212

Cite this article as: Khakhla $\mathrm{PH}$, Anand $\mathrm{R}$, Sharma JG, Boghara BB. Role of cytology, colposcopy and biopsy in the detection of cervical intraepithelial neoplasia. Int J Reprod Contracept Obstet Gynecol 2013;2:550-4. 